\title{
A SAUDE E A EDUCAÇÃO COMO QUESTÃO SOCIAL E POLITICA*
}

Ignez Salas Martins ${ }^{1}$

MARTINS, I. S. A Saúde e a Educação como Questão Social e Política. Rev. Bras. Cresc. Des. Hum. 1(2): 1991.

\section{RESUMO}

O presente texto apresenta uma reflexão sobre a questão da saúde, a partir de metodologia que procura contemplar o ser humano com totalidade. Nesse contexto, é discutido o crescimento e o desenvolvimento da criança, apontando-se a creche como espaço privilegiado para a realização dessas duas dimensões de saúde.

\section{INTRODUÇÃO}

Ao se abordar o tema "A Saúde e a Educação como Questão Social e Polltica”, é necessário, inicialmente, desenvolver algumas considerações $\operatorname{coI}^{\wedge}$ lceituais e tentar demonstrar que ambas questões se integram.

Embora a saúde se expresse, antes de mais nada, pela disposição fisica, longevidade, ausência de morbidade, a higidez está condicionada ao ambiente social. e físico que determinam a doença, a homeostase e a própria normalidade biológica. Em outras palavras, subjacente a essa normalidade, existe uma normatividade social que pode ou não ser compatível com essa dimensão. Portanto, ao se refletir sobre a saúde, referida apenas ao corpo e a suas funções organizas e não ao ser humano como totalidade, pode-se cometer o pecado do tratamento parcial da questão.

A saúde como conceito amplo já foi reconhecida desde os primórdios da Saúde Pública. Reich, Virchow, Leubscher, Neumann e outros, no século passado, apontavam a saúde como componente do bem-estar, reivindicando-a como direito de todo cidadão e dever do Estado. Açóes de saúde, segundo esses pensadores, envolviam o ser humano como um todo, em todas as suas "condições e relações”. Por sua vez, na década de 40, deste século, a Organizacáo Mundial de Saúde (OMS) defmiu a saúde como um estado de "bemestar físico, mental e social e não mera ausência de doença”. Refletir sobre a saúde implica, portanto, em buscar, na análise da sociedade e na sua história, os elementos que compõem o "bem-estar", assim como sugerir a viabilidade e a legitimidade de leis ou instituições necessárias à sua consecução.

Os elementos que compõem o "bem-estar” seriam a expressão das condições essenciais de sobrevivência do grupo social. Por um lado, isto se representa através do consumo de alguns "bens fundamentais", historicamente determinados, que permitem a reprodução do homem na sua condição de integrante de uma sociedade. Neste sentido, a saúde se impõe como questão social e política, como um bem público e, nessa condição, como dever do Estado. Assim, a saúde só é tangível ao se criar condições sociais concretas que garantam um "mínimo vital", compatível com a sobrevivência dentro dos padrões

\footnotetext{
* Palestra preferida no Seminário “Encontro sobre Creches”, promovido pelo CDH e pela Faculdade de Saúde Pública/USP, em São Paulo, em outubro/86.

1 Professora associada do Departamento de Nutrição da Faculdade de Saúde Pública/ USP - Ar. Dr. Arnaldo, 715—CEP 01255 -
} São Paulo-SP - Fone: (011) 52-6748. 
de dignidade de cada grupo social. Portanto, a apropriação de bens de consumo coletivos necessários à promoção e à manutenção da saúde seria, nas sociedades democráticas, um direito inalienável de todo cidadão.

Por outro lado, no exercício do direito à saúde reconhecese, atualmente, a necessidade fundamental do cidadão de participar do planejamento, da organização, do controle e da execução de programas em torno de metas estabelecidas dentro da própria comunidade, em contato com técnicos e representantes de instituições governamentais, responsáveis por políticas setoriais e globais. Essa busca da consulta popular e da participação do povo no exercício da função pública vem recuperar a idéia da comunidade como expressão da solidariedade humana e promover a dignidade do homem, tornando-o participante e ativo na construção da vida social. Por sua vez, a participação na funcão pública ocorre na medida em que o indivíduo está devidamente integrado na cultura; em outras palavras, na medida em que contempla a própria cidadania.

A formação do cidadão como agente não sé do seu destino, mas também do desenvolvimento global, traz implícita a necessidade da apropriação da cultura pelas classes. A cultura, neste sentido, será a integração dos valores culturais locais, vividos pelo homem em seu cotidiano e condicionado a uma situação de classe, com uma cultura mais universal envolvendo a idéia da nacionalidade e da própria cidadania. É dentro desse raciocínio que a saúde e a educação se colocam como questão social e política, cujos elementos se complementam harmonicamente. Neste aspecto é que a creche se destaca como espaço privilegiado do cresci- mento e do desenvolvimento, entendendo-se que este, entre outras coisas, se realiza na apropriação da cultura e na possibilidade de agir criticamente sobre ela. Sabe-se, há muito, que não basta o alimento para tornar a criança um ser humano produtivo e inteligente. E necessário que se lhe forneça oportunidades para que se torne integrante da cultura e tenha condições de assimilá-la de acordo com os seus esquemas próprios de açao. $\mathrm{O}$ conhecimento que se transmite à criança nada mais é do que elementos para uma adaptação progressiva ao mundo real que é a cultura. $\mathrm{O}$ conhecimento expressa, portanto, a apropriação dos elementos materiais e espirituais da cultura. Dessa dinamica resulta a capacidade de agir criticamente e recriar a realidade.

A saúde contemplada como elemento inerente à cidadania está relacionada com novos papéis que uma sociedade moderna avançada deve destinar à representação do Estado e à expressão do povo. Envolve a ruptura da situação de précidadania de grupos componentes do corpo social, entre os quais a criança. Ao invés de intervenções de cunho caritativo ou benevolente, é pre ciso assegurar os benefícios como direito e se estabelecer legislação que viabilize a participação popular. Isso desenha um modelo que demanda a redefinição da relação entre o Estado e o povo, que só ocorrerá quando a população se apropriar da cidadania e tiver real participação no projeto de desenvolvimento danação. É por isso que a formação do cidadão tem, na creche, o seu espaço privilegiado, onde é fundamental se resguardar os direitos da criança como cidadã, pois o país do futuro repousara na maneira como o crescimento e o desenvolvimento interag $\wedge \mathrm{l}^{\wedge} \operatorname{lem}$ com a Sociedade. 